\title{
Integral-Universal Education: Analysis of M. Natsir's Thoughts on Islamic Education
}

\author{
Kasmuri Selamat \\ Universitas Islam Negeri (UIN) Sultan Syarif Kasim, Riau, Indonesia \\ kasmuri31@gmail.com
}

\begin{abstract}
This paper aimed at exploring M. Natsir's thoughts on Islamic education. Using a qualitative study with a historical approach, the writer found that M. Natsir was a rare figure. He was not only a scholar but also a thinker, a politician, and an educator. As an educator, he not only became a teacher, but also gave birth to various educational concepts known as an integral and universal education concept. He was an architect and an anti-dichotomous thinker of Islamic education. According to Natsir, Islam did not separate spiritual matters from worldly affairs. The spiritual aspect would be the basis of worldliness. The foregoing indicated that religious ethics emphasized by Islamic teachings must be the foundation of life. The conceptual basis of "educational modernism" with tauhid as its foundation demonstrated that he was a figure who really cared about Islamic education.
\end{abstract}

Keywords: Integral-Universal Education, M. Natsir, Thought

\section{Introduction}

Minangkabau, West Sumatra, is one of the areas that cannot be underestimated because there are many great figures on the national and international scales in various fields of expertise from this area, such as scholars, politicians, and other strategic fields. Among these figures are Tuanku Imam Bonjol, Haji Agus Salim, Sutan Sjahrir, Hamka, M. Natsir, and others. Everybody knows these names and their works.

These figures lived in the early $20^{\text {th }}$ century when three ideological groups competed with one another to dominate in the struggle for independence. The three groups were Islam, secular nationalism, and communism. In the early days of Indonesian independence, another ideological group known as socialism emerged. In the era of independence, these ideologies were promoted by political parties. Secular nationalism was supported by the new Indonesian National Party 
(in Indonesian abbreviation, PNI); communism was promoted by the Indonesian Communist Party (in Indonesian abbreviation, PKI); and socialism was espoused by the Indonesian Socialist Party (the so-called Parsi, later changed to PSI). In this case, according to Hertbet Feith, there were five ideologies that developed at the beginning of the country's own growth, namely Islam, nationalism, communism, socialism, and Javanesetraditionalism (Herbert Feith and Lance Castle, 1986).

Competition and challenges from these non-Islamic ideologies drove Islamic figures, including Natsir, to critically assess various ideologies that already developed in Indonesia. This step was then followed by formulating an Islamic ideology. As the mediators, Islamic leaders including Agus Salim, Sukiman Wirjosandjojo, Wachid Hasyim, and M. Natsir, M. Roem initiated to establish an Islamic party. They planned a congress that incorporated representatives of Islamic groups in Indonesia. A congress committee was formed, and M. Natsir was positioned as the chairman.

The congress further known as the "the Congress of Indonesian Muslim Ummah" held in Yogyakarta, the $7^{\text {th }}-8^{\text {th }}$ of November 1945 , was attended by no fewer than 500 people consisting of Islamic figures and the general public (Bachtiar, 2012: 70-71). The congress resulted in the establishment of Masyumi Party as a 'single party' channeling the political aspirations of Indonesian Muslims (Kedaulatan Rakyat No. 8 / dated 9 November 1945; Noer, 1987: 19; Mahendra, 1999: 62).

M. Natsir's seriousness in responding to the challenges at the beginning of the $20^{\text {th }}$ century was not merely active in political organizations, but he was active in a religious organization concerned with education and preaching as well. The organization was called the Islamic Union (in Indonesian acronym as Persis). His decision to get engaged into Persis was not without reason. For him, Persis could be a bridge for the struggle in dealing with various problems faced by Muslims at that time. For Natsir, Persis was an organization with selected people that were accountable.

M. Natsir also felt that Persis as a socio-religious and educational organization had something in common with his mindset and his bases of 
struggles. As well-known, this organization was committed to fighting for Islamic teachings based on the Qur'an and Sunnah. Also, Persis concentrated on preaching and education by expanding the spread of Islamic tabligh and da'wah' (Ajip Rosyidi, 1990: 39).

As a Mujtahid devoting all of his thoughts (ijtihad), M. Natsir subsequently spawned his thoughts on integral and universal Islamic education based on the Qur'an and Sunnah with tauhid as the ideology. The contribution of M. Natsir's thoughts in the field of education can definitely face the reality of Islamic education which is undergoing intellectual deadlock, the term used by Abd. Rahman Assegaf. The foregoing can be identified from several indications such as the lack of renewal efforts, the practice of Islamic education nowadays that has not yet been constructed on creative, innovative, and critical thinking as regards actual issues, the educational learning model which is more dominant in an intellectualism-verbalistic approach, and the orientation of Islamic education merely oriented towards the formation of 'abd (servants of Allah) but not yet balanced with the attainment of Muslims' character as the prosperity agents and leaders on earth (khalifah fi alardh) (Agung, 2017: 44).

In terms of data and the means of data analysis, the type of this study is categorized as a qualitative study, aiming to reveal the findings with respect to M. Natsir's thoughts of Islamic education (Moleong, 2007: 6; Cobin, 1997: 11). The method applied is the historical method to search, examine, and critically analyze the past track records and attempt to synthesize data into a reliable historical presentation (Gottschalk, 2008: 39; Barnadib, 1982: 38).

Corresponding to the primary data source, the researcher studies and presents M. Natsir's thoughts on Islamic education sourced from his manuscripts and scientific works. The secondary data are solicited from the written works of others about M. Natsir, Dakwah dan Pemikirannya by Thohir Luth; Natsir, Politik Santun Di antara Dua Rezim by the KFG team of writers, M. Natsir Sebuah Biografi by Aji Rosidi, M. Natsir 70 Tahun edited by Yusuf Abdullah Puar, and others.

\section{Natsir's Biography}


Alahan Panjang is a fertile plateau known as Gumanti Valley. In this area lie many coffee, vegetable, and rice fields. The air condition is considered healthy and cold because this area is located under the Mount Talang. In addition, the panoramic views of lakes in the upper and lower parts of the area and the river stream of Batang Hiliran Gumanti add to the beautiful sensation of this area. The river cannot be separated from Natsir's life. In a house on the edge of a lake that is part of Solok Regency, West Sumatra, a man named Mohammad Natsir was born (the $17^{\text {th }}$ of July 1908). He was the son of a writer named Idris Sutan Saripado and a mother named Khadijah. In accordance with Minangkabau's tradition, growing up as an adult, the name Natsir was equipped with a customary title called Mohammad Natsir Datuk Sinaro Panjang (Rhoma Dwi Aria Yuliantri, 2015: 47). In 1918, Sutan Saripado changed his job from a writer to a guard from Alahan Panjang to Ujung Pandang, Sulawesi. In a village where he was born, little Natsir spent his time learning religion, and his intellectuals were honed by his three siblings (Yukinan, Rubiah, and Yohanusun) (Salam, 1990: 131).

Just like many boys on the ground of Minang, little Natsir learned the Qur'an at a mosque called Surau Dagangdi around Alahan Panjang (the KFG team of writers, t.t: 8; Bukhari Umar, 2009: 211). At the age of 18 years old (1926), Natsir wanted to enter HIS (Holland Inlandse School). However, it was not undertaken because he was just a son of a lowly employee (Thohir Luth, 1999: 22). Therefore, whenever he saw the sturdy stone-walled building in the city of Padang, the young Natsir's heart always shook. The memory of being the son of a lowly employee (a writer) that was refused to enter the school was unforgottable. However, Natsir did not lose himself in disappointment. He subsequently entered HIS Adabiah Padang, a special school in Padang.

However, it did not mean that after entering HIS Adabiah Padang, the young Natsir lived in a very comfortable life. He passed five months of a life full of struggles. Natsir lived independently, but he lived his life happily. In fact, this raised his awareness that happiness did not belong to the rich but to those who had a calm heart, and those who did not just surrender and give up on circumstances (Yusuf Abdullah Puar, 1978: 4). After several months of schooling in Padang, M. Natsir moved to the 
Governmental HIS in Solok due to his father's request. Because of his intelligence, he immediately sat in class 01. Solok was where Natsir studied Arabic and jurisprudence from Tuanku Mudo Amin at the first time, in the afternoon at Madrasah Diniyah, and in the evening he studied the Qur'an (Deliar Noer, 1990: 100).

In 1920, Natsir moved to Padang at the request of his older sister, Rubiah. This lowered the burden of his life. So, Natsir graduated from HIS in 1923, in the span of seven years (1916-1923). Subsequently, Natsir studied at HIS and Madrasah Diniyah in Solok and in Padang (Thohir Luth, 1999: 22). After graduating from HIS, Natsir received information about MULO (Meer Uitgebreid Lager Orderwijs) school in Padang that offered scholarship. MULO was similar to the level of junior high school. He applied for a scholarship, and he was finally accepted. At MULO of Padang, he began to become active in organizations. He joined organizations called Jong-Sumatranen-Bond or the Sumatran Youth organization and Jong-Islamieten-Bond (Islamic Youth organization), and Pandu Nationale Islamietische Pavinderij (Natipji) which was similar to Scouts (Anwar, 2020: 185). For Natsir, organizations would complement his knowledge (education) as a candidate for the nation's leader (Yusuf Abdullah Puar, 1978: 4).

M. Natsir did not feel enough if his education was just ended up with MULO. After graduating from MULO, his desire to study in Java was very strong. He was eager to migrate to Java to continue his intellectual journey. He expressed his wish to his parents so that he could enter AMS (Algemeeene Middelbare School), similar to the level of high school in Bandung. Natsir chose the literature department. His dream of studying at a school on the land of Parahiangan eventually came true by means of a scholarship program (Hepi Andi Bastoni et al, 2008: 4).

In Bandung, M. Natsir built interactions with many religious figures as well as thinkers whose religious thoughts and understanding were aligned with his. He met A. Hassan who influenced his thinking (Nata, 2005: 75). Besides studying formally at AMS Bandung, Natsir also joined the Jong Islameten Bond (JIB) movement organization consisting of Indonesian students studying in the Netherlands. This organizational experience made M. Natsir, at a very young age (20 years old), interacted 
with major national figures (Mahendra, 1994: 65). Besides, M. Natsir discussed each other with his peers. His outstanding intellectuality and competence allowed him to occupy the chair of the JIB Bandung (19281932). Automatically, his political abilities would be honed. Various activities that he took part in influenced his thinking (Yusuf Abdullah Puar, 1978: 20).

After graduating from AMS with honors, Natsir obtained a scholarship to study at the Rechtnische Hoge School (the High School of Law) in Batavia (Jakarta) or the College of Economics in Rotterdam, the Netherlands. Natsir really aspired to become Meester de Rechten, a legal expert. However, along with a change in his thinking, Natsir did not take a scholarship to continue to the law school, but he immersed himself to actively write, organize, and establish a school (Djaini, 1996: 106). The private school on Jalan Lengkong Besar No. 16 Bandung, that he established, was the result of a discussion with A. Hassan. He even immediately became a teacher with a salary of Rp. 17.50. For Natsir, this was an idealist project.

M. Natsir established the Islamic Education Institute known as Pendis to overcome the phenomenon of public schools that did not teach religion. He became not only the founder but also the director. He served for ten years since 1932 and developed in West Java and Jakarta (Thohir Luth, 1999: 24). Subsequently, in 1938, M. Natsir began to be active in politics by participanting in the Indonesian Islamic Association (in Indonesian abbreviation called PII) in Bandung. Two years later, in 19401942, he was trusted to be the Chairman. In the same year (1940-1942), he also worked as the Head of Education Bureau for the city of Bandung (1945). At the same time, he was also trusted as the secretary of the Islamic High School (the so-called STI) in Jakarta (Yusril Ihza Mahendra, 1994: 65). STI Jakarta was the only Islamic College established after independence. In 1945-1946 (post-independence of Indonesia), M. Natsir became a member of the Central Indonesian National Committee (known as KNIP). Later, Sjahrir needed Islamic support for his cabinet, so he was appointed to be Minister of Information. This was agreed by Bung Karno even though he had a polemic with M. Natsir. Bung Karno said "Hij is de man", he was the one (Mohammad Natsir / Mohammad Roem 70 Years 
Commemoration Committee, 1978: 7). He became the minister of information in two cabinets, the Syahrir 1-2 cabinet, and the 1st Hatta cabinet. M. Natsir's career in reaching this level of central government was supported by his strategic steps in the parliamentary session of the Republic of Indonesia (RIS) on April 3 ${ }^{\text {rd }}$, 1950, which was better known as the "Integral Natsir Motion" (Thohir Luth, 1999: 25), which allowed the Republic of Indonesia to be reunited, that previously had by chance split into 17 (Floriberta Aning S, 2005: 139).

The format of M. Natsir's struggle then changed. That he initially entered the world of politics changed into the direction of da'wah. He formed the Indonesian Islamic Da'wah Council (known as DDII) Foundation located in Jakarta. He was not alone, but he established the foundation together with the Ulama who were also Masjumi former activists. Although the format of his struggle experienced a change, his critical and corrective attitude towards the government never subsided. This situation made a gap in his relationship with the government, even full of tension. His courage to participate in signing Petition 50 on May $5^{\text {th }}$, 1980 , caused him to be banned from abroad without a clear legal process, during this state, until his death.

The fragrance of M. Natsir's name was also smelled overseas. This was due to his international preaching activities. The peak of his popularity was indicated by his interactions with international Islamic figures. Together with Sheikh Maulana Abul A'la al-Maududi (Lahore) and Abu Hasan al-Nadwi (Lucnow), M. Natsir chaired the Alam Islamy Congress in Damascus, 1956. Not only that, Natsir was also entrusted as the Vice President of the World Islamic Congress based in Pakistan (Solichin Salam, 1990: 132). As an appreciation for M. Natsir's dedication to the Islamic world, he was awarded the Doctor of Honoris Causa (DR. HC.) from various countries (Thohir Luth, 1999: 27).

Finally, Natsir's struggle in the world ended. He was picked up by the Almighty on the $6^{\text {th }}$ of February 1993 AD in a coincidence with the $14^{\text {th }}$ of Sya'ban 1413 Hijriah, at the Cipto Mangkunkusumo Hospital, Jakarta, at the age of 85 years old. The news of his death became the headlines in various print and electronic media. Various expressions of condolences emerged from both his peers and his political opponents. Not only from 
the domestic media, but the news of M. Natsir's death was also published in foreign media (Bukhari Umar, 2011: 216-2017).

\section{Natsir's Written Works}

M. Natsir was not only an activist that drove an organization but also an intellectual who consistently shared his ideas into writing. M. Natsir's written works which later became books concerned various issues of politics, economy, education, preaching, and others. Although his works did not refer to one field merely, if observed, these works were connected to one another, which presented Islam as the main trend.

Yusuf Abdullah Puar (1978: 4) mentioned that there were about 52 titles of works that he produced since 1930. The titles on various occasions were later published as books as follows: The New Morality (Moral Baru); Islam dan Kristen di Indonesia; Di Bawah Naungan Risalah; Dakwah dan Pembangunan; Dari Masa Ke Masa; Pendidikan, Pengorbanan Kepemimpinan, Primordialisme, dan Nostalgia; Indonesia di Persimpangan Jalan; Mempersatukan Umat Islam; Kebudayaan Islam dalam Perspektif Sejarah; Asas keyakinan Agama Kami; Bahaya Takut; Kom Tot Het Gebed; Pandai- pandailah Bersyukur Nikmat; Dakwah dan Pembangunan; Tolong Dengarkan Pula Suara Kami; World Of Islam Festival Dalam Perspektif Sejarah; Mempersatukan Umat Islam; Kebudayaan Islam dalam Perspektif Sejarah; Pandai- pandailah Bersyukur Nikmat; Dunia Isam Dari Masa Ke Masa; Tauhid Untuk Persaudaraan Islam Universal; Iman Sebagai Sumber Kekuatan Lahir Dan Batin; Kumpulan Khutbah Dua Hari Raya; and Demokrasi di Bawah Hukum.

Some of the books above show that other than being concerned about the implementation of Islamic teachings in the life of the nation and state, M. Natsir also developed education for the people. The implementation of Islamic teachings plays a significant role in empowering the Ummah. Through this education, Natsir hoped that Muslims must follow the guidelines of the Qur'an and Hadith. Also, according to him, Muslims must master religious knowledge and general knowledge at the same time, not separating the two sets of knowledge such as water and oil.

\section{Natsir's Islamic Education Concept}


From the life history and some of M. Natsir's works, it seems that he is very responsive to social problems, including the problems of education in Islamic boarding schools and madrasah. His responsiveness was evident in his involvement in educational institutions by participating in establishing the Islamic Unity Islamic Boarding School (Persis) in Bandung in March 1936. He was involved with his administrators and teachers who voluntarily sacrificed their time and energy for the Pesantren. They included R. Abdul Kadir (an alumnus of the Bandung Engineering School) who taught engineering, and Hassan who was concurrently the head of the pesantren. Natsir was also a lecturer in education in addition to an advisor (Syafig A. Mughni, 1994: 69)

M. Natsir's motivation of gettig engaged into the education implemented by the Islamic Union (Persis) derived from a thought and aspiration to build a harmonious system with the nature and Islamic teachings. Natsir's understanding of religion and education developed after he met Ahmad Hassan, a man from Singapore, an Indian descent, who later became a religious expert at the Bandung Islamic Union (Persis) organization. The meeting and continuous discussions with Ahmad Hikiran made Natsir's mind flourish. In addition to exchanging ideas, the two of them also worked hand in hand in raising the Pembela Islam newspaper. Apart from being a journalist, Natsir and Ahmad Hassan also served as the persons in charge and the editors in chief of the Pembela Islam newspaper (Yusuf Abdullah Puar, 1978: 15-17).

One of the changes in Natsir's thinking due to exchanging ideas with Ahmad Hassan was about the open Islamic education. According to Natsir, education must have a place of spiritual dependence, meaning that it does not only serve the power of reason and logic alone. Natsir interpreted spirituality into the word tauhid which is then used as a basis for thinking about education (Rhoma Dwi Aria Yuliantri, 2015: 48).

Globally, Muhammad Natsir's education concept consists of five components, including integral-universal education, the concept of Islamic education, educational ideology, the role and function of education, educational goals, and the function of foreign languages. 


\section{The Concept of Integral-Universal Education}

The concept of education that is integral and universal is a wellknown educational concept from M. Natsir. The concept of combining intellect, morality, and spirituality is part of this integration. Meanwhile, the Universal concept means that education must be comprehensive. M. Natsir argued, "The decline and progress of education do not depend upon the East and West; they do not depend on white, yellow, or black colors of skin; but they depend on the presence or absence of characteristics and potential of people's abilites that make them worthy or not occupy a glorious place in this world".

M. Natsir's concept is reflected in his reaction to the sociohistorical conditions he finds in people's lives. This concept is unique and has not even existed before in Islamic society. The existing concept of education is only parochial, differential, and dichotomous. This condition, according to him, happens because Muslims have got too long caught in the thoughts of Sufism and colonialism (A. Susanto, 2015: 119). This concept of education is echoed by the mission to spread Islam, which is universal. Islam not only teaches the relationship between servants and God, but also provides guidance that is useful as a view of human life. This universal nature means that Islam knows no boundaries of countries and continents, so there is no conflict in science. This means, if the knowledge is true and good even though it comes from Western and Eastern countries, then Muslims may use it as a guide and reference. In addition, according to him, progress in Islamic education is not measured by worldly mastery but can provide assets for ukhrawi life (A. Susanto, 2015: 120).

\section{Basic Education}

M. Natsir revealed that devoting or believing in God must be the basis for every education in every generation. The concept or basis of Deity as such is very important and needs to be applied (Natsir, 2015: 10). Besides, according to him, the concept of Tauhid is related to the morality of al-karimah. Tauhid will be formulated on noble morals such as the birth of a sense of sincerity, honesty, courage, and a sense of responsibility to carry out obligations that are believed to be true (Abuddin Nata, 2005: 86) 
From the above view, it is found that the basis of Islamic education is the Qur'an and hadith based on Tauhid. Monotheistic education teaches man to enslave himself only to Allah SWT. It aims to glorify human beings in this world and the hereafter. Slavery can be interpreted as a form of fear, obedience, and human submission to his Rabbi (Allah SWT). To create the success of life in this world and the victory of the hereafter, it takes mastery of science and technology as well as skills. In other words, a human being who fears Allah SWT means that he already has knowledge because to become a true servant of Allah SWT, he must have knowledge.

\section{Role and Function of Education}

One of the challenges faced by M. Natsir at that time was the assimilation or Indonesianization launched by the Dutch colonial government. This assimilation or Indonesianization was an attempt by the colonial government to embrace important Indonesian figures so that they had a view and were oriented towards Den Haag, so that slowly their view of life as an Indonesian nation would be forgotten. Besides, they also recruited smart students, and they were then taken care by the families of Dutch nationality and / or who adhered to Christianity. Their mission was successful. This was proven by Amir Syarifuddin who was Muslim but then converted to Protestant Christianity (M. Natsir, 1987: 4).

Seeing this phenomenon, M. Natsir emphasized education that functions to liberate, namely conscious and sustainable efforts to humanize humans so that they can actualize themselves (Syaiful Anwar, 2017: 91). Therefore, education must have the role and function of education that humanizes humans and plays a role in making humans become servants of God, not servants of other humans. On this basis, M. Natsir proposed six educational formulas as follows:

1. Education must function as a means to educate humans in order to achieve perfect physical and spiritual growth and development.

2. Education must be directed to form students who have human characteristics in order to achieve the moral of al-karimah (noble morallity).

3. Education must be a means to produce honest and true human beings.

4. Education must play a role in realizing humans who can reach the core of their life, namely becoming 'abd, true servants of Allah. 
5. Education must be able to make people who in all their daily activities become rahmatan li al-'alamin.

6. Education should really encourage the perfection of humanity but not eliminate and alienate it (Bukhari Umar, 2009: 218).

\section{Educational Objectives}

Addressing the purpose of Islamic education, it cannot be separated from the purpose of human creation. The purpose of human creation as mentioned in QS. Adz-Dariyat verse 56 is to worship Allah (serve Him). The purpose-related details of human life are described by M. Natsir as the purpose of Islamic education. According to Natsir, education must be taught to learners as the capital in facing life as the best creation of God and as the khalifah fi al-ardh (leaders and posperity agents on earth) (M. Natsir, 1954: 83).

Furthermore, according to Natsir, as the leaders and the prosperity agents on earth that are exalted by Allah, humans should carry out Allah's orders and do good deeds to others, and perform worship towards their God (Surah Al-Baqarah: 177). Explicitly, humans must have at least six characteristics, namely first, having faith and monotheism which is reflected in his daily behavior; second, having a philanthropic spirit; third, always having a vertical relationship with God by carrying out prayers continuously; fourth, strengthening horizontal relationships with fellow human beings by distributing part of the assets they own; fifth, having noble morals marked by commitment in fulfilling the promises that have been made; and sixth, having a strong soul in facing unpleasant situations and conditions.

Resting on the above formula, M. Natsir wanted the birth of productive human beings who contribute to their nation, country, and religion. However, such productivity should be based on worshiping God, as a form of self-service to God who has inspired them to work. Such worship and slavery must also be seen in the framework of life's struggles for the prosperity of mankind.

Foreign Language Function 
Appertaining to the urgency of foreign languages, especially Dutch and Arabic, Natsir suggested that foreign languages be taught and understood by the following steps:

1. Arabic is mandatory for Elementary Schools, Secondary Schools, and Academies. Otherwise, the university or school will not have many Arabic speaking students.

2. Knowledge of the Arabic language should be mandatory for all services involving Middle Eastern affairs such as diplomatic, trade and business relations, banking, exchange of tourists and delegations with the aim that they consider Arabic speaking countries their own home.

3. Students who are proficient and skilled at Arabic must be sent to Arabic countries, upgrading Arabic language and literature on the condition that they return and serve Arabic in their country.

4. The existing Arabic teaching syllabus should be rejected and replaced with a new one, alive, strong, powerful, and beautiful. Likewise, grammar must also be arranged easily because the complexity and rigid methods used so far have created a tedious learning atmosphere and do not lead people to the capability of using foreign languages.

5. Arabic should now receive the same attention as classical Arabic that is to read and understand the news in newspapers, television, and the official language of government in conjunction with legal, political, diplomatic or speech-related terms, speeches, agreements and official routine reports that do not exist in the classical language.

6. The increasing tendency to teach Islam without knowing Arabic in the Islamic and non-Arabic world is extremely dangerous. This will only cause humans to be far from their original sources. More essentially, currently there is no knowledge or education that has been accepted without knowing the original source directly. It must be remembered that the originality cannot be replaced by translations. As a result of this tendency, Islamic students or students in Islamic universities do not know Arabic well.

7. The main literature must be translated accurately into the dominant languages, so that interest in Arabic can increase and 
further introduce students to the original sources. The scholars who work in this field must be encouraged and publish their works.

8. Scientific, linguistic or phonetic language teaching methods should be used to accelerate the speed of teaching Arabic to nonArabic students, in the shortest possible time (Abuddin Nata, 2005: 92).

M. Natsir's thoughts on the importance of these foreign languages, especially Arabic for Muslims, are underpinned by that Arabic is the key to unlocking knowledge and understanding Islamic teachings. Without mastering it, it is impossible for Muslims to understand Arabic books that have been written by previous scholars and Islamic figures which contain very comprehensive knowledge.

\section{Conclusion}

M. Natsir is a mujtahid who is rich in various concepts or ideas. His views on Islam (religion) and the state have been subject to study. Likewise, the concept of Islamic education giving birth to the concept of an integral and universal Islamic education based on tauhid is a relevant concept to be practiced today. Hence, M. Natsir deserves to be called a Thinker and Architect of Islamic Education. An integrative education model based on tauhid (divinity) needs to be applied, so that there is no dichotomy between general and religious education.

\section{References}

Anwar, Syaiful dan Abdul Hakim El Hamidy,Biografi Tokoh Pendidikan Islam Sumatera Barat. Bandung: Hakim Publishing, 2017.

Anwar, Syaiful dan Sabda Mustafa. Tokoh Pembaharuan Pendidikan Islam Sumatera Barat. Kab. Lima Puluh Kota: CV. Mazaya, 2020.

Bachtiar, Tiar Anwar dan Pepen Irpan Fauzan, Persis dan Politik: Sejarah dan Aksi Politik Persis 1923-1997, Jakarta: Pembela Islam Media dan PW Persis Jawa Barat, 2012.

Barnadib, Soetari Imam, Pengantar Pendidikan Ilmu Pendidikan Sistematis, Yogyakarta: FIP-IKIP Yogyakarta, 1984. 
Bastoni, Hepi Andi dkk, Mohammad Natsir Sang Maestro Dakwah, Jakarta : Mujtamaa Press, 2008.

Djaini, Abibullah, Pemikiran dan Perjuangan Mohammad Natsir.Jakarta: Pustaka Firdaus, 1996.

Feith, Herberth dan Lance Catles (Ed), Pemikiran Politik Indonesia 19451965 (terjemahan), Jakarta: LP3ES.

Gottschalk, L. 2009. Mengerti sejarah. Terjemahan Nugroho Notosusanto. Jakarta: UI-Press.

Khumaidi. "Islam dan Tata Negara: Pemikiran Sosial-Politik Mohammad Natsir", dalam Jurnal Penelitian Sosial dan Keagamaan Kontekstualita, Volume 20, Nomor 1, Juni 2005.

Puar, Yusuf A, M. Natsir 70 Tahun:Kenang-kenangan Kehidupan Perjuangan Islam. Jakarta: Pustaka Antara, 1978.

Luth, Thohir, M. Natsir, Dakwah dan Pemikirannya. Jakarta: Gema Insani Press, 1999.

Madjid, Nurcholis et.al, Kehampaan Spiritual Masyarakat Modern: Respons dan Transformasi Nilai-nilai Islam menuju Masyarakat Islam Madani, Jakarta: Mediacita, 2001, cet. ke-5

Mahendra, Yusril Ihza. "Modernisme Islam dan Demokrasi: Pandangan Politik M. Natsir", dalam Jurnal Islamika, Nomor 3, Januari-Maret, 1994.

Nata, Abuddin. 2003. Pemikiran Para Tokoh Pendidikan Islam. Jakarta: PT.RajaGrafindo Persada, 2003.

Natsir, Mohammad. Capita Selecta, Jilid 1. Jakarta: Bulan Bintang, 1973.

-----. 1981. Fiqhud Da'wah. Semarang: Ramadhani

-----. 1987. Pendidikan, Pengorbanan, Kepemimpinan, Primordialisme dan Nostalgia, Jakarta: Media Dakwah, 1987, cet. ke-1.

Noer, Deliar, Gerakan Islam Modern 1900-1942, Jakarta: LP3ES, 1990.

Panitia Peringatan M. Natsir/Mohammad Roem 70 Tahun, M. Natsir 70 Tahun, Kenang-kenangan Kehidupan dan Perjuangan, t.t: Pustaka Antara, 1978. 
Puar, Yusuf Abdullah, M. Natsir 70 Tahun: Kenang-kenangan Kehidupan dan Perjuangan, Jakarta: Pustaka Antara, 1978.

Ramayulis, "Pemikiran M. Natsir tentang Pendidikan", Hadharah, Vol. I. No. 1

S, Floriberta Aning,100 Tokoh Yang Mengubah Indonesia: Biografi Sejarah Singkat Seratus Tokoh yang Paling Berpengaruh dalam Sejarah Indonesia di Abad 20. Yogyakarta: Penerbit NARASI, 2005.

Salam, Solihin, Wajah Nasional, Jakarta: Pusat Studi dan Penelitian Islam, 1990.

Susanto, A. Pemikiran Pendidikan Islam, Jakarta : Amzah, 2015.

Tim Penulis, Natsir Politik Santun di Antara Dua Rezim. Jakarta: KFG (Kepustakaan Populer Gramedia), t.th

Yuliantri, Rhoma Dwi Aria, et.al, Tokoh Pemikir Karakter Bangsa, Jakarta: Direktorat Sejarah dan Nilai Budaya Direktorat Jenderal Kebudayaan Kementerian Pendidikan dan Kebudayaan, 2015. 